\title{
PENGARUH BIAYA OPERASIONAL (BOPO), BAGI HASIL DANA PIHAK KETIGA (DPK), CASH RATIO TERHADAP MARGIN MURABAHAH PADA BANK UMUM SYARIAH
}

\author{
${ }^{1}$ Lady Vini Maharani Lubis, ${ }^{2}$ Zufrizal Harahap, ${ }^{3}$ Zenni Riana, ${ }^{4}$ Sri Rahayu, ${ }^{5}$ Syamsul Effendi, ${ }^{6}$ Eli Agustami \\ Universitas Islam Sumatera Utara \\ lady19maret@gmail.com, ${ }^{2}$ ZZufrizal@uisu.ac.id, ${ }^{3}$ Zenni.riana@fe.uisu.ac.id, ${ }^{4}$ sri.rahayu@fe.uisu.ac.id, \\ ${ }^{5}$ syamsul.effendi@fe.uisu.ac.id, ${ }^{6}$ eli.agustami@fe.uisu.ac.id
}

\begin{abstract}
The purpose of this study is to analyze whether Operational Costs (BOPO) affect Murabahah Margin in Sharia Commercial Banks, know whether Third Party Fund Revenue Sharing (DPK) affects Murabahah Margin in Sharia Commercial Banks, know if Cash Ratio affects Murabahah Margin in Sharia Commercial Banks. And aims to find out if Operational Costs (BOPO), Third Party Fund Revenue Sharing (DPK), and Cash Ratio jointly affect Murabahah Margin in Sharia Commercial Banks from 2016 to 2019. The data analysis methods used to test hypotheses in this study are descriptive analysis tests, classic assumption tests, multiple linear regression analysis tests, and hypothesis tests. The results of this study showed that variable Operational Costs (BOPO), Third Party Fund Revenue Sharing (DPK), and Cash Ratio simultaneously or jointly have a significant influence on Murabahah Margin. While partially having different influences, Operating Costs (BOPO) have a positive and significant effect on Murabahah Margin, Third Party Fund Revenue Share (DPK) has no significant effect on Murabahah Margin, and Cash Ratio has no significant effect on Murabahah margin.
\end{abstract}

Keywords : Oprasional Cost (BOPO), Third party fund share (DPK), Cash ratio, Murabahah Margin

ABSTRAK : Tujuan penelitian ini merupakan untuk menganalisa apakah Biaya Operasional (BOPO) berpengaruh terhadap Margin Murabahah pada Bank Umum Syariah, mengetahui apakah Bagi Hasil Dana Pihak Ketiga (DPK) berpengaruh terhadap Margin Murabahah pada Bank Umum Syariah, mengetahui apakah Cash Ratio berpengaruh terhadap Margin Murabahah pada Bank Umum Syariah. Serta bertujuan buat mengetahui apakah Biaya Operasional (BOPO), Bagi Hasil Dana Pihak Ketiga (DPK), dan Cash Ratio secara bersama-sama berpengaruh terhadap Margin Murabahah Pada Bank Umum Syariah dari tahun 2016 sampai dengan tahun 2019. Metode analisis data yang digunakan untuk menguji hipotesis dalam penelitian ini adalah uji analisis deskriptif, uji asumsi klasik, uji analisis regresi linear berganda, dan uji hipotesis. Hasil penelitian ini menunjukkan bahwa variabel Biaya Operasional (BOPO), Bagi Hasil Dana Pihak Ketiga (DPK), dan Cash Ratio secara simultan atau secara bersama-sama memberikan pengaruh signifikan terhadap Margin Murabahah. Sedangkan secara parsial memiliki pengaruh yang berbeda-beda, Biaya Operasional (BOPO) berpengaruh Positif dan signifikan terhadap Margin Murabahah, Bagi Hasil Dana Pihak Ketiga (DPK) tidak berpengaruh signifikan terhadap Margin Murabahah, dan Cash Ratio tidak berpengaruh signifikan terhadap margin Murabahah.

Kata Kunci : Biaya oprasional (BOPO), Bagi hasil dana pihak ketiga (DPK), Cash ratio, Margin Murabahah

\section{Pendahuluan}

Margin murabahahsekarang adalah keuntungan yg lebih banyak didominasi oleh perbankan syariah di Indonesia, namun banyak kritikan yg dilontarkan dalam bank syariah pada kasus menetapkan margin". Murabahah adalah pembiayaan bank yg bersifat jual beli menggunakan pedoman laba atau margin dan pada jangka yang tertentu. Akad murabahah dievaluasikianminim resiko daripada menggunakan bagi hasil. kemudianmenentukanmargin diawal maka mempermudah bank saatmemperhitungkankeuntungan yg didapat. 
Menurut Miftakhatul (2014:4) Margin Murabahah adalah kesepakatan pembiayaan berdasarkan yang mempunyai dana kepada yang menerima dana, dimana pada pertamakaiperjanjian sudah disepakati terlebih dahulu tentang besarnya pembiayaan \& margin laba antara ke 2 belah pihak tersebut. Penerima dana sudah menyepakati besaran margin yg bersifat fixed hinggadiakhir waktu, kemudian besaran taraf margin yg harus dibayarkan oleh nasabah akan serupa berdasarkan tahun pertama beliau melakukan pembayaran, sampai berakhir ketika waktu pembiayaan. Menurut Sakti (2014:4) Margin pada global perbankan syariah adalah sebuah kata yg dipakai buat memberitahukan pendapatan yg didapat dari kelainandari akad jual beli. Margin wajib telah dipenuhi saat awal pada perjanjian \&takbisadiubah di tengahjalan.

Menurut (Rossalina, 2017)Faktor pertama yg diduga mensugesti margin murabahah merupakan biaya operasional. "Biaya operasional adalah seluruh jenis biaya yg berkaitan eksklusif menggunakan bidang bisnis bank. Secara generik biaya operasional dimaknai menjadi biaya yg terjadi pada kaitannya menggunakan operasi yg dilakukan perusahaan \& diukur pada satuan uang. Bebanbeban pada laporan ini merupakan beban-beban yg dimuntahkan oleh bank syariah menjadi institusi keuangan syariah sendiri, tidak terdapat kaitannya menggunakan pengolaan dana bagi hasil,beban tenaga kerja, beban umum \& administrasi \& beban-beban lainnya". Biaya operasional adalah komponen yg sebagai acuan buat memutuskan besaran harga pada mengenakan beban pada nasabahnya. Sementara itu,yang diharapkan banklaba maupun margin yg terus semakin tinggi tetapi tak seterusnya bank syariah menjalani syarat yg diinginkan, lantaran buat menggapai laba yg semakin meningkat, bank syariah harus memikirkanbagian biaya operasional yg tak menutup peluangbisaberpengaruh.

Menurut Wahyudi (2017:7)Faktor kedua yang menyandang pengaruh dengan margin murabahah ialah Bagi Hasil Dana Pihak Ketiga (DPK). Guna perbankan syariah selain itu adalah untuk menghimpun dana asal masyarakat. Menurut Rossalina(2017:1492) Bagi hasil dana pihak ketiga (DPK) adalah yg wajib disediakan bank pada rangka memberikan imbalan atau bonus pada klien, juga pihak yg dananya diolah bank menggunakan konvensi nisbah pada awal. nasabah penabung menggunakan skema mudharabah \& wadi'ah menciptakan wajib menyiapkan dana bagi hasil untuk laba yg didapat pada nasabah. Maka dari itu, supaya bisa menyalurkan secara optimal, bank wajib mempunyai kemampuan pada saat menghimpun Dana Pihak Ketiga ini adalah asal premier pembiayaan bank syariah. Besarnya bagi hasil dana pihak ketiga memengaruhi terhadap pendapatan margin murabahah.

Menurut Miftakhatul (2014:5) Faktor ketiga yang memiliki pengaruh terhadap margin murabahah adalah cash ratio. Menurut Nasyaroeka(2016:27) Cash ratio adalah alat yg dipakai buat mengukur banyak uang kas yg tersedia buatbayar hutang.Cash ratiosungguhkrusialuntuk perusahaan, lantaran maka cash ratio yg relatif naik kepercayaan nasabah juga naik. Tetapiyg berlebih pun tak bagus, lantaran ada dana yg tak produktif, \& kesempatan untuk mendapat laba akan berkurang.

Tabel 1.Perkembangan Margin Murabahah pada Bank Umum Syariah periode 2016 sampai dengan 2019

\begin{tabular}{|c|r|r|}
\hline Nama Perusahaan & Tahun & $\begin{array}{c}\text { Margin } \\
\text { Murabahah }\end{array}$ \\
\hline PT. Bank BNI Syariah & 2016 & 0,072 \\
\cline { 2 - 2 } & 2017 & 0,023 \\
\cline { 2 - 2 } & 2018 & 0,041 \\
\cline { 2 - 2 } & 2019 & 0,014 \\
\hline PT. Bank BRI Syariah & 2016 & 0,184 \\
\cline { 2 - 2 } & 2017 & 0,122 \\
\cline { 2 - 2 } & 2018 & 0,166 \\
\cline { 2 - 2 } PT. Bank Muamalat Indonesia & 2019 & 0,241 \\
& 2016 & 0,086 \\
\cline { 2 - 2 } & 2017 & 0,051 \\
\cline { 2 - 2 } & 2018 & 0,021 \\
\cline { 2 - 2 } & &
\end{tabular}




\begin{tabular}{|c|r|r|}
\hline \multirow{2}{*}{ Nama Perusahaan } & Tahun & $\begin{array}{c}\text { Margin } \\
\text { Murabahah }\end{array}$ \\
\cline { 2 - 2 } & 2019 & 0,015 \\
\hline \multirow{2}{*}{ PT. Bank BCA Syariah } & 2016 & 0,130 \\
\cline { 2 - 2 } & 2017 & 0,085 \\
\cline { 2 - 2 } & 2018 & 0,054 \\
\cline { 2 - 2 } & 2019 & 0,058 \\
\hline
\end{tabular}

Tabel diatas memperlihatkan perkembangan Margin murabahah pada tahun 2016 2019.mengalami ketidakstabilan setiap tahunnya oleh Bank BNI dan BRI Syariah.berbeda hal dengan Bank Muamalat dan BCA Syariah yg mengalami penurunan setiap tahunnya. Dapat dilihat pada tabel dinyatakan bahwasannya margin murabahah pada Bank umum Syariah setiap tahunnya mengalami ketidakstabilan, dikarenakan beberapa faktor yang pertama yaitu Biaya Operasional, Bagi Hasil Dana Pihak Ketiga (DPK) dan Cash Ratio. Semua variabel didalam penelitian ini perlu diperhatikan karena merupakan tolak ukur bagi perbankan.

Berikut keterangan penelitian sebelumnya yang menghubungkan dengan variabel dependen. penelitian ini sejalan penelitian terdahulu, penelitian Zulfahmi (2018) menyatakan Biaya Operasional mensugesti positif \& signifikan terhadap Margin murabahah. Biaya operasional menjadi biaya yg terjadi pada kaitannya menggunakan operasi yg dibuat perusahaan \&mengukurpada satuan uang. beban pada laporan ini merupakan beban yg diberikan bank syariah menjadi lembaga keuangan syariah. Dan ini tak ada kaitan menggunakan pengolaan dana bagi hasil. Penjelasan penelitian yg terhubung dengan variabel dependen lainnya yaitu dari penelitian terdahulu, penelitian Sakinah (2018) yg menjelaskan bahwa Bahwa "Bagi Hasil Hasil Dana Pihak Ketiga (DPK) tidak berpengaruh positif \& signifikan terhadap Margin Murabahah". "Bahwa apabila meningkat tingkat Cash Ratio maka ketidaksignifikanan mensugesti pendapatan Margin Murabahah pada Bank Umum yang terdapat di Indonesia".

kajian ini dilaksanakan sebab terdapat ketidaksamaan fakta yang terjadi di lapangan dengan teori (theory gap) juga perbedaan hasil kajian yang berbeda dan hasil yang tidak persisten (Research Gap)dengan pengaruh Biaya Operasional (BOPO), "Bagi Hasil Dana Pihak Ketiga (DPK), dan Cash Ratiodengan Margin Murabahah". Sehingga peneliti melakukan replikasi dari penelitian sebelumnya untuk dilakukan pengujian kembali menggunakan masing-masing variabel. Guna mengklasifikasikan kajian ini dengan kajian lainnya, maka penulis perlu menggabungkan 3 variabel di penelitian yang berbeda dengan mempergunakan Bank Umum Syariah yg sudah terdaftar di OJK tahun 2016 hingga 2019.

\section{LANDASAN TEORI}

\subsection{MARGIN MURABAHAH}

Menurut Rahma (2016:45) "Margin Murabahahdipengaruhi oleh biaya-biaya yang dimuntahkan\&sasaran keuntungan yg diharapkan. Margin Murabahahdipengaruhi oleh pembiayaan, biaya overhead \&profit”.Penelitian ini menggunakan rumus :

\section{Cost recovery + Keuntunga yang diharapkan Harga beli $\times 100 \%$}

\subsection{BIAYA OPERASIONAL (BOPO)}

Menurut Rahayu(2014:10) "Biaya Operasional merupakan seluruh biaya yg dikeluarkan perusahaan dalam waktu aktivitas operasi perusahaan padasaat satu tahun periode akuntansi”. Selain itu Biaya Operasional merupakan biaya yg terjadi buat diolahnya bahan baku ke produk jadi yg siap buat dijual. Penelitian ini menggunakan rumus :

Biaya Operasional

$$
\begin{aligned}
& =\frac{\text { Beban Operasional }}{\text { Pendapatan Operasional }} \\
& \times 100 \%
\end{aligned}
$$

\subsection{BAGI HASIL DANA PIHAK KETIGA (DPK)}

Menurut Khasanah(2018:34)"Dana Pihak Ketiga (DPK)pada produk perbankan syariah merupakan dana yg dihimpun menurut masyarakat berupa simpanan terdiri atas giro wadi'ah, tabungan wadi'ah, tabungan mudharabah dan deposito mudharabah, ternyata adalah asal dana terbesar yg paling diandalkan bank". Penelitian ini menggunakan rumus: 


$$
D P K=\text { Giro }+ \text { Tabungan }+ \text { Deposito }
$$

\subsection{CASH RATIO}

Menurut Bunaya (2013:20) "Cash Ratio adalah bagian dari ukuran dan rasio likuiditas (liquidity ratio) yg adalah kemampuan perusahaan memenuhi kewajiban jangka pendeknya (current liability) melalui sejumlah kas (setara kas misalnya giro atau simpanan lain padabank yg bisa ditarik setiap saat) yg dimiliki perusahaan".Penelitian ini menggunakan rumus:

\section{Kas + Setarakas

Kewajiban Lancar

\section{Metode Penelitian}

\subsection{Populasi Penelitian}

Menurut Amirullah(2015:68) Populasi adalah hilostik menurut kumpulan elemen yg mempunyai sejumlah ciri umum, yg terdiri menurut bidang-bidang yg akan diteliti. Populasi menurut kajian ini adalah semua bank umum Syariah yang ada di Indonesia tahun 2016-2019 yang berjumlah sebanyak 14 perusahaan.

\subsection{SAMPEL PENELITIAN}

Teknik pengambilan sampel dalam penelitian ini adalah menggunakan metode purposive sampling. Menurut Mukhsin et al (2017:190) Purposive sampling merupakan teknik menentukan sampel menggunakan pertimbangan tertentu. Dimana pengambilan sampel berdasarkan atas kriteria-kriteria yg dirumuskan terlebih dahulu dari sang peneliti. Sampel diambil bukan secara acak, tetapi dipengaruhidari peneliti menggunakan pertimbangan atau kriteria tertentu".

\section{Hasil Penelitian \\ 4.1. Analisis Descriptif}

Tabel 2. Output Uji Deskripsi

Descriptive Statistics

\begin{tabular}{|c|c|c|c|c|c|}
\hline & $\mathrm{N}$ & Minimum & Maximum & Mean & $\begin{array}{c}\text { Std. } \\
\text { Deviation }\end{array}$ \\
\hline Biaya Operasional & 32 & ,31 & 2,55 & ,6154 &, 47725 \\
\hline $\begin{array}{l}\text { Bagi Hasil dana } \\
\text { Pihak Ketiga }\end{array}$ & 32 & $\begin{array}{r}4567470,0 \\
0\end{array}$ & $\begin{array}{r}6114011299 \\
195,00\end{array}$ & $\begin{array}{r}6062265737 \\
69,1876\end{array}$ & $\begin{array}{r}1252190650 \\
398,30300\end{array}$ \\
\hline Cash Ratio & 32 & ,09 & 1,76 & ,7529 & ,41391 \\
\hline Margin Murabahah & 32 &,- 95 & 1,45 &, 1073 & ,38554 \\
\hline Valid N (listwise) & 32 & & & & \\
\hline
\end{tabular}

Menurut tabel 2 bisa dilihat bahwasannya diperoleh keterangan terlihat Biaya Operasional dengan nilai terendah atau nilai minimum adalah 0,31 , sementara itu nilai tertinggi atau maksimum sebesar 2,55 dengan nilai rata-rata 0,6154 dan standar deviasi 0,47725. Sementara itubisa terlihat dari variabel Dana Pihak Ketiga (DPK) atas nilai terendah atau nilai minimun adalah 4567470,00dannilai tertinggi atau nilai maksimum sebesar 6114011299195,00 nilai rata-rata $606226573769,1876 \& \quad$ standar deviasi1252190650398,30300. Kemudian dapat dilihat dari variabel Cash Ratio dengan nilai terendah atau nilai minimum 0,09 , sedangkan nilai tertinggi atau nilai maksimum sebesar 1,76 , dengan nilai rata-rata 0,7529 dan standar deviasi 0,41391 . Selanjutnya dapat dilihat di variabel $Y$ yaitu Margin Murabahah menunjukkan nilai terendah atau nilai minimum adalah $-0,95$ nilai tertinggi atau nilai maksimum 1,45 , dengan nilai rata-rata 0,1073 dan standar deviasi 0,38554 .

\subsection{Uji Asumsi Klasik 4.2.1. Uji Normalitas}

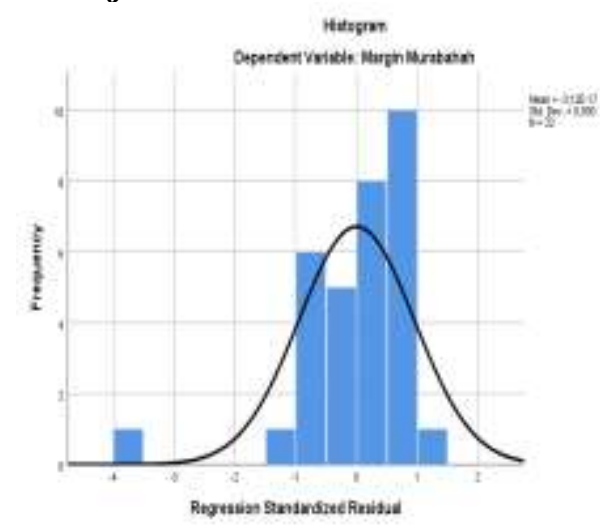

Gambar.1 Histogram 


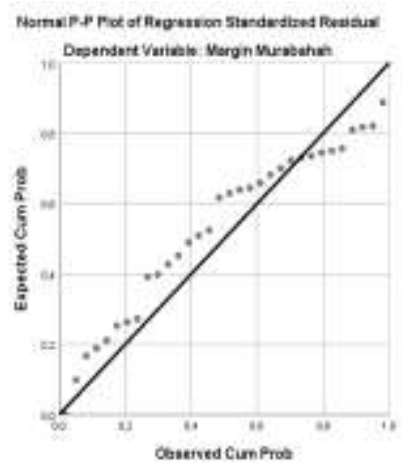

residual terdistribusi secara normal.dalam grafik normal P-Plot dihasilkan pola distribusi pada titik-titik tersebarberhimpit padakurang lebih diagonal \&ke 2 ini memperlihatkan bahwa residual terdistribusi dengan cara normal”.

Gambar 2. Grafik Normal P-Plot

Dapat dicermati bahwa grafik histogram menaruh pola terdistribusi yg tak melenceng ke arahkiri \&arah kanan. makabisa disimpulkan

Tabel 3. Output Kolmogorof-Smirnov

One-Sample Kolmogorov-Smirnov Test Unstandardized Residual

\begin{tabular}{llr}
\hline $\mathrm{N}$ & & 32 \\
\hline Normal & Mean &, 0000000 \\
\cline { 2 - 3 } $\begin{array}{l}\text { Parameter } \\
\mathrm{s} \text { a,b }\end{array}$ & Std. Deviation &, 18040112 \\
\hline Most & & Absolute \\
\cline { 2 - 3 } $\begin{array}{l}\text { Extreme } \\
\text { Differenc }\end{array}$ & Positive &, 154 \\
\cline { 2 - 3 } $\mathrm{es}$ & Negative &,- 154 \\
\hline Test Statistic &, 154 \\
\hline Asymp. Sig. (2-tailed) &, $053^{\mathrm{c}}$ \\
\hline $\begin{array}{l}\text { a. } \text { Test distribution is Normal. } \\
\text { b. Calculated from data. } \\
\text { c. Lilliefors Significance Correction. } \\
\text { Sumber : SPSS 25,00 Tahun 2020 }\end{array}$ \\
\end{tabular}

Tabel 3 membuktikan hasil uji normalitas buat data yang dianalisis. Uji normalitas menggunakan menguji normalitas residual \& sebesar 0,053 diatas nilai signifikan 0,05bisadisimpulkan bahwa model regresi bisa dilihat melalui nilai Asymp (2-Tailed)

\subsubsection{Uji Multikolinearitas}

Tabel 4.Output Multikolinearitas

\section{Coefficients $^{\mathrm{a}}$}

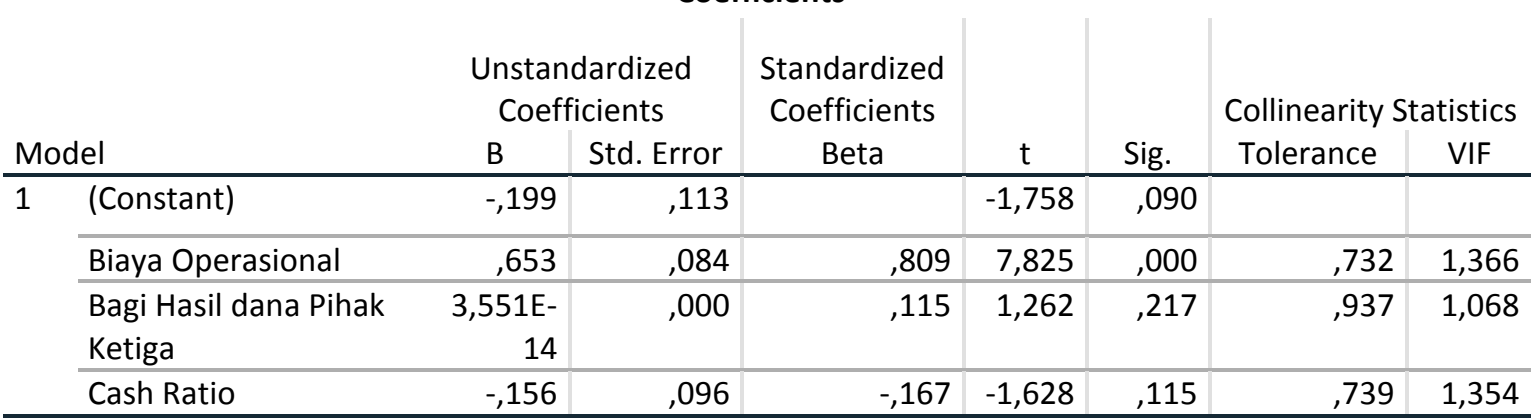

a. Dependent Variable: Margin Murabahah 
Pada hasil perhitungan yg ditunjukkan untuk tabel uji multikolinearitas, dimana bisa dicermati bahwa seluruh variabel yg dipakaipada penelitian ini mempunyai nilai tolerance yg lebih pada 0,1 \& nilai VIF yg kurang 10. Hal ini berarti bahwa tak terdapat gejala multikolinearitas antar semua variabel independen padakajiaanini.Makabisa dikatakan contoh yg berbentuk merupakan contoh regresi yg baik\& layak dipakai pada penelitian.

\subsubsection{Uji Heteroskedastisitas}

\subsubsection{Uji Autokorelasi}

Tabel 5. Output Autokorelasi

Model Summary ${ }^{\mathrm{b}}$

\begin{tabular}{|c|c|c|c|c|c|}
\hline \multirow{2}{*}{ Model } & \multirow[b]{2}{*}{$\mathrm{R}$} & \multicolumn{2}{|r|}{ 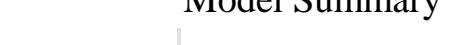 } & \multirow[b]{2}{*}{$\begin{array}{l}\text { Std. Error of the } \\
\text { Estimate }\end{array}$} & \multirow[b]{2}{*}{ Durbin-Watson } \\
\hline & & R Square & $\begin{array}{l}\text { Adjusted R } \\
\text { Square }\end{array}$ & & \\
\hline 1 &, $884^{\mathrm{a}}$ & , 781 &, 758 & ,18982 & 2,308 \\
\hline
\end{tabular}

Dari hasil SPSS di tabel 4.5 di atas telah didapat nilai Asymp. Sig(2-tailed) sebesar $0,059,>0,05$ sehingga bisaditarik kesimpulan nilai residual menyebar secara acak dan tidak

ada gejala ataupun terjadi masalah autokorelasi dalam persamaan regresi sehingga analisis regresi linear bisa dilanjutkan.

\subsection{Uji Hipotesis}

\subsubsection{Analisis Regresi Linear Berganda}

Tabel 6. Output Analisis Regresi Linear Berganda Coefficients $^{\mathrm{a}}$

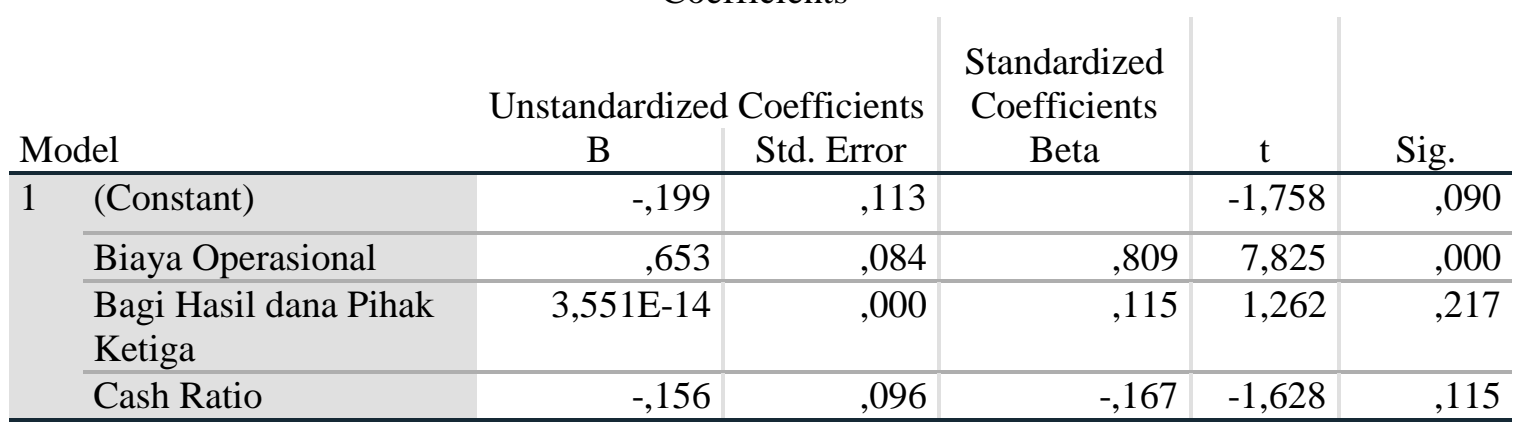

a. Dependent Variable: Margin Murabahah

Berdasarkan tabel 4.5 hasil pengujian menggunakan metode regresi linear berganda di atas yang melakukan pengujian hubungan variabel-variabel

independent Biaya Operasional lalu dapat disusun sebuah persamaan sebagai berikut : 
$Y=-0,199+0,653 X_{1}+3,551 X_{2^{-}} 0,156 X_{3}+e$

Persamaan regresi diatas mempunyai makna sebagai berikut :

1) Konstanta sebesar $\quad-0,199$ menerangkanapabila variabel independen dianggap bernilai nol, lalu margin murabahah bank bernilai sebesar -0,199".

2) Koefisien regresi $X_{1}$ (Biaya Operasional) pada saat memperhitungan linear berganda bisaterlihat sebesar 0,653keadaan ini bermaknapadakenaikan biaya operasionalsebesar 1 satuan maka margin murabahah bank akan meningkat0,653 satuan. kebalikannya, saat terjadi penurunan biaya operasional sebesar 1 satuan maka margin murabahah bank menurun sebesar 0,653 satuan".
3) Koefisien regresi $X_{2}$ (bagi Hasil Dana Pihak Ketiga (DPK)) saat memperhitungkan linear berganda bisa terlihat 3,551keadaan ini bermaknasaat terjadi peningkatan Bagi Hasil Dana Pihak Ketiga (DPK) sebesar 1 satuan maka Margin Murabahah akan menurunkn sebesar 3,551 satuan. Sebaliknya setiap ada penurunan Bagi Hasil DPK sebesar 1 satuan maka Margin murabahah maka naik sebesar 3,551 satuan".

4) Koefisien regresi $X_{3}$ (Cash Ratio)saat memperhitungkan linear berganda bisa terlihat $-0,156$ keadaan inisaat meningkatcash ratio sebesar 1 persen diprediksi maka turun pendapatan margin murabahah sebesar -0,156, dengan asumsi margin murabahah tidak berubah".

\subsubsection{Uji Koefisien Determinan $\left(\mathbf{R}^{2}\right)$}

Tabel 7. Output Hasil Analisis Koefisien Determinan

\begin{tabular}{|c|c|c|c|c|c|}
\hline \multirow[b]{2}{*}{ Model } & \multicolumn{4}{|c|}{ Model Summary } & \multirow[b]{2}{*}{ Durbin-Watson } \\
\hline & $\mathrm{R}$ & R Square & $\begin{array}{l}\text { Adjusted R } \\
\text { Square } \\
\end{array}$ & $\begin{array}{l}\text { Std. Error of the } \\
\text { Estimate }\end{array}$ & \\
\hline 1 &, $884^{\mathrm{a}}$ & ,781 &, 758 &, 18982 & 2,308 \\
\hline
\end{tabular}

Tabel memperlihatkan nilai koefisien determinasi (adjust $R$ ) yang diperoleh sebesar 0,758 atau $75,8 \%$. Keadaan ini memperlihatkan variabel Biaya Operasional, Bagi Hasil Dana Pihak Ketiga (DPK) dan Cash Ratio berkontribusi sebesar 24,2\% dipengaruhi variabel lainnya yg tak diperiksa didalam penelitian ini.

\subsubsection{Uji Parsial (Uji t)}

\begin{tabular}{|c|c|c|c|c|c|c|}
\hline \multirow{3}{*}{\multicolumn{2}{|c|}{ Model }} & \multicolumn{5}{|c|}{$\begin{array}{c}\text { Tabel 8. Output Hasil Uji T } \\
\text { Coefficients }^{\mathrm{a}}\end{array}$} \\
\hline & & \multicolumn{2}{|c|}{$\begin{array}{l}\text { Unstandardized } \\
\text { Coefficients }\end{array}$} & \multirow{2}{*}{$\begin{array}{l}\text { Standardize } \\
\mathrm{d} \\
\text { Coefficients } \\
\text { Beta }\end{array}$} & \multirow[b]{2}{*}{$\mathrm{t}$} & \multirow[b]{2}{*}{ Sig. } \\
\hline & & $\mathrm{B}$ & Std. Error & & & \\
\hline \multirow[t]{4}{*}{$\overline{1}$} & (Constant) &,- 199 &, 113 & & $-1,758$ &, 090 \\
\hline & Biaya Operasional & 653 & 084 & 809 & 7,825 & 000 \\
\hline & $\begin{array}{l}\text { Bagi Hasil dana } \\
\text { Pihak Ketiga }\end{array}$ & $3,551 \mathrm{E}-14$ & ,000 &, 115 & 1,262 & ,217 \\
\hline & Cash Ratio &,- 156 & ,096 &,- 167 & $-1,628$ & 115 \\
\hline
\end{tabular}

Berlandaskan hasil uji di tabel maka bisa diambil kesimpulan sebagai berikut :

1) Biaya Operasional memiliki nilai yang signifikan sebesar $0,000<0,05$ hipotesis diterima. Ini bermakna variabel tersebut mempunyaimemengaruhi positif dan signifikan terhadap Margin Murabahah.

2) Bagi Hasil Dana Pihak Ketiga (DPK) mempunyai nilai signifikan 0,217> 0,05 hipotesis ditolak. Keadaan ini bermakna 
variabel tersebut takmemengaruhi signifikan terhadap Margin Murabahah.

3) Cash Ratio memiliki nilai yang tidak signifikan sebesar 0,115> 0,05 maka hipotesis ditolak. Keadaan ini berarti variabel tersebut tak memengaruhi terhadap Margin Murabahah.

\subsubsection{Uji Statistik F}

\begin{tabular}{|c|c|c|c|c|c|c|}
\hline \multicolumn{7}{|c|}{$\begin{array}{l}\text { Tabel 9. Output Hasil Uji F } \\
\text { ANOVA }^{\mathrm{a}}\end{array}$} \\
\hline Model & & $\begin{array}{l}\text { Sum of } \\
\text { Squares }\end{array}$ & df & Mean Square & $\mathrm{F}$ & Sig. \\
\hline \multirow[t]{3}{*}{1} & Regression & 3,599 & 3 & 1,200 & 33,295 &, $000^{\mathrm{b}}$ \\
\hline & Residual & 1,009 & 28 & ,036 & & \\
\hline & Total & 4,608 & 31 & & & \\
\hline
\end{tabular}

Pemeriksaan menggunakan uji $\mathrm{F}$ dibuat untuk melihat apa Biaya Operasional, Bagi Hasil Dana Pihak Ketiga (DPK) dan Cash Ratio secara bersama-sama berpengaruh signifikan terhadap Margin Murabahahdi perusahaan dengan level pengujian hipotesis 5\% menggunakan uji hipotesis yg diharuskan. Berdasarkan uji $\mathrm{F}$, didapat $\mathrm{F}_{\text {hitung }}$ 33,295 dengan signifikan 0,000. Berlandaskan hasil itu diambil kesimpulan bahwasannya Biaya Operasional, Bagi Hasil Dana Pihak Ketiga (DPK) \&Cash Ratio berpengaruh terhadap Margin Murabahah.

\section{Kesimpulan}

1) Secara parsial variabel Biaya Operasional (BOPO) berpengaruh positif dan signifikan terhadap Margin Murabahahpada Bank Umum Syariah, yang berarti bahwa data Biaya Operasional menunjukkan keadaan bahwa manajemen bank mempertimbangkan besaran biaya operasional dalam memperhitungkan tingkat margin murabahah bank syariah. Tingkat biaya operasional merupakan variabel pengurang penghasilan bank. Oleh karenanya bank perlu mempertimbangkan biaya operasional sebagai salah satu penentu tingkat presentase margin guna menghindari kerugian yang dihadapi bank".

2) Secara Parsial variabel Bagi Hasil Dana Pihak Ketiga (DPK) tidak memengaruhisignifikan terhadap Margin Murabahahdi Bank Umum Syariah. Yang artinya saat simpanan dana pihak ketiga yg dihimpun Bank Umum Syariah di Indonesia naik maka Margin Murabahah yg akan turun. DPK terukurmenggunakan jumlah tabungan, giro \& deposito dalam Bank
Umum Syariah pada menjalankan aktivitasnya berfungsi sebagai intermediasi sebagai akibatnya sehabis berhasil menghimpun dana berdasarkan pihak ketiga, bank syariah berkewajiban menyalurkan dana tadi buat pembiayaan".

3) Secara parsial variabel Cash Ratio tidak berpengaruhsignifikan terhadap Margin Murabahahpada Bank Umum Syariah, sbagai akibatnya bisa disimpulkan bahwa meningkat tingkat Cash Ratio maka tidak menghipnotis secara signifikan pendapatan margin murabahahdalam Bank Umum Syariah di Indonesia. Hal tadi lantaran likuiditas berasal menurut kapital inti, dana titipan \& kuasi ekuitas, sebagai akibatnya meningkatCash Ratio maka pendapatan margin pula akan meningkat".

4) Secarasimultan Biaya Operasional (BOPO), BagiHasil Dana Pihak Ketiga (DPK), Cash Ratio Berpengaruh positif \& signifikan terhadap Margin MurabahahPada Bank UmumSyariah".

\section{DAFTAR PUSTAKA}

Agung, M. (2017). Perhitungan harga pokok kamar hotel aryaduta makassar.

Amirullah. (2015). Populasi dan sampel (pemahaman, jenis dan teknik). Wood Science and Technology, 16(4), 293-303. https://doi.org/10.1007/BF00353157

Apriyono, A. (2013). Analisis overreaction pada harga saham perusahaan manufaktur di bursa efek indonesia. Jurnal Manajemen, 9(1), https://doi.org/10.29264/jmmn.v9i1.2473

Bunaya, E. R. (2013). Pengaruh cash ratio, debt equity ratio dan earnings per share terhadap cash dividend pada perusahaan 
jasa non keuangan yang terdaftar di Bursa efek Indonesia (BEI) period 2006-2009.

Dewi, C. P. M. (2019). Pengaruh Biaya Operasional dan Volum Pembiayaan Musyarakah Terhadap Margin Bank Periode Tahun 2016-2018 di Bank BNI Syariah cabang Pintu Batu Kota Bengkulu.

Fidyah. (2017). Analisis Pendapatan Margin Murabahah Pada Bank Muamalat Indonesia. Jurnal STIE Semarang, 9(1), 20-31.

Ghozali, I. (2011). Aplikasi analisis multivarat dengan program IBM 19.

Ghozali, I. (2013). Aplikasi analisis multivarate dengan SPSS.

Hidayati, V. N. (2019). Analisis Pengaruh Dana Pihak Ketiga ( Dpk ), Financing To Deposit Ratio ( $F d r$ ), Capital Adequacy Ratio ( Car ) Terhadap Profitabilitas Dengan Tingkat.

Khasanah, N. (2018). Pengaruh DAna Pihak Ketiga (DPK) dan Capital Adequacy ratio (CAR) terhadap pembiayaan dengan non performing financing (NPF) sebagai variabel moderating. Journal of Chemical Information and Modeling, 01(01), 16891699.

Latifah, U. (2012). Pengaruh Rasio Keuangan terhadap perubahan laba pada bank umum Syariah di Indonesia period 2007-2011.

Marlina, R. N. dan A. (2013). Sistem Pengalokasian dan pengendalian operasional pada PT Telkommetra. Journal of Chemical Information and Modeling, 01(01), 16891699.

Meissy, P. F. (2019). Pengaruh Disiplin Kerja Dan Fasilitas Kerja Terhadap Kinerja Karyawan Pada Kedai 27 Di Surabaya. Agora, 7(1), 287221.

Miftakhatul. (2014). Pengaruh Biaya Operasional, Non performing finance $(N P F)$, dan cash ratio terhadap pendapatan margin murabahah pada PT Bank Muamalat Indonesia, Tbk. 66, 37-39.

Muhson, A. (2013). Teknik Analisis Kuantitatif. Makalah Teknik Analisis II, 1-7. http://staffnew.uny.ac.id/upload/132232818/ pendidikan/Analisis+Kuantitatif.pdf

Mukhsin, R., Mappigau, P., \& Tenriawaru, A. N. (2017). Pengaruh Orientasi Kewirausahaan Terhadap Daya Tahan Hidup Usaha Di Kota Makassar. Jurnal Analisis, $6(2)$

3. http://pasca.unhas.ac.id/jurnal/files/ef79bd33 0d16ba9fda32510e0a581953.pdf
Mulya, A. (2018). Pengaruh Pembiayaan mudharabah, musyarakah, murabahah dan non performin financing terhadap profitabilitas bank umum syariah period 2012-2016.

Mutiara, R. (2017). Peran Bank Syariah dalam pemberdayaan usaha nelayan di pulau pasaran (studi pada bank syariah Mandiri kantor cabang Teluk Betung). PhD Proposal, $\quad$ l(October), 2016. https://doi.org/10.1017/CBO9781107415324 .004

Nana Diana dan Syamsul Huda. (2019). Dana pihak ketiga dan pendapatan pembiayaan bagi hasil terhadap laba pada Bank Umum Syariah Indonesia. $A \gamma \alpha \eta, \quad 8(2), 2019$. https://doi.org/10.22201/fq.18708404e.2004. 3.66178

Napitupulu, L. A. (2017). Pengaruh Komitmen Organisasional, Motivasi Dan Kompetensi Terhadap Kinerja Manajerial Pada Rumah Sakit Swasta Di Kota Pekenbaru. Jurnal Online Mahasiswa Bidang Ilmu Ekonomi, 4(1), 338-352.

Nasyaroeka, J. (2016). Analisis Komparative Cash Ratio dan Debt To Assets Ratio Terhadap Return On Assets Pada Perusahaan Retail Trade dan Perusahaan Telekomunikasi yang Terdaftar Di Bursa Efek Indonesia. JUrnal Magister Manajemen, 02(01).

Ningrum, A. I. (2019). Analisis Dana pihak ketiga, kecukupan modal, kredit bermasalah dan profitabilitas pada PT. Bank Sumut Kantor Pusat Medan.

Purwanti, A. (2013). Analisis kas Ratio dan Pembiayaan murabahah pngaruhnya terhadap pendapatan margin murabahah pada Bank Muamalat Indonesi, Tbk. Riset Akuntansi, V(2).

Rahayu, S. (2014). Analisis pengaruh biaya operasional terhadap kinerja keuangan pada PT.PLN (Persero) wilayah Selselrabar.2014(June), 1-2. https://repositories.lib.utexas.edu/handle/215 2/39127

Rahma, Y. (2016). Faktor-Faktor Yang Mempengaruhi Margin Murabahah Bank Syariah Di Indonesia. Akuntabilitas, 9(1), 43-54.

https://doi.org/10.15408/akt.v9i1.3584

Rambe, S. (2018). Pengaruh kinerja keuangan terhadap tingkat bagi hasil deposito mudharabah pada pt. bank sumut cabang syariah katamso medan skripsi. 
Rossalina, R. (2017). Analisis Pengaruh Biaya Operasional, Volume Pembiayaan Murabahah dan Bagi Hasil DPK Terhadap Margin Pembiayaan Murabahah Studi Kasus Pada Bank Umum Syariah di Indonesia Tahun 2010-2014. JOM Fekom, 1(2),1389-1403.

Sakti, H. S. (2014). Pengaruh Biaya Operasional dan Tingkat Suku Bunga Terhadap Margin Pembiayaan Murabahah Pada PT. Bank Mega Syariah Indonesia. Applied Microbiology and Biotechnology, 85(1), 2071-2079. https://doi.org/10.1016/j.bbapap.2013.06.00 7

Sirgar, sofyan. (2014). Statistik parametrik untuk penlitian kualitatif.

Suprensam. (2016). Analisis tingkat likuiditas pada PT. Unilever, Tbk. Journal of Chemical Information and Modeling, 53(9), 1689-1699.

Wahyudi, R. (2017). Pengaruh ROA, DPK, Inflasi dan BI Rate Terhadap Margin Pembiayaan Murabahah Perbankan Syariah di Indonesia.

Wahyuningrum. (2018). Pengaruh Dana Pihak Ketiga, Non Perfoming Financial, Biaya Operasional Pendapatan Operasional, Margin Murabahah Terhadap Pembiayaan Murabahah Pada Bank Umum Syariah Di Indonesia. Journal of Chemical Information and Modeling, 53(9), 1689-1699. 